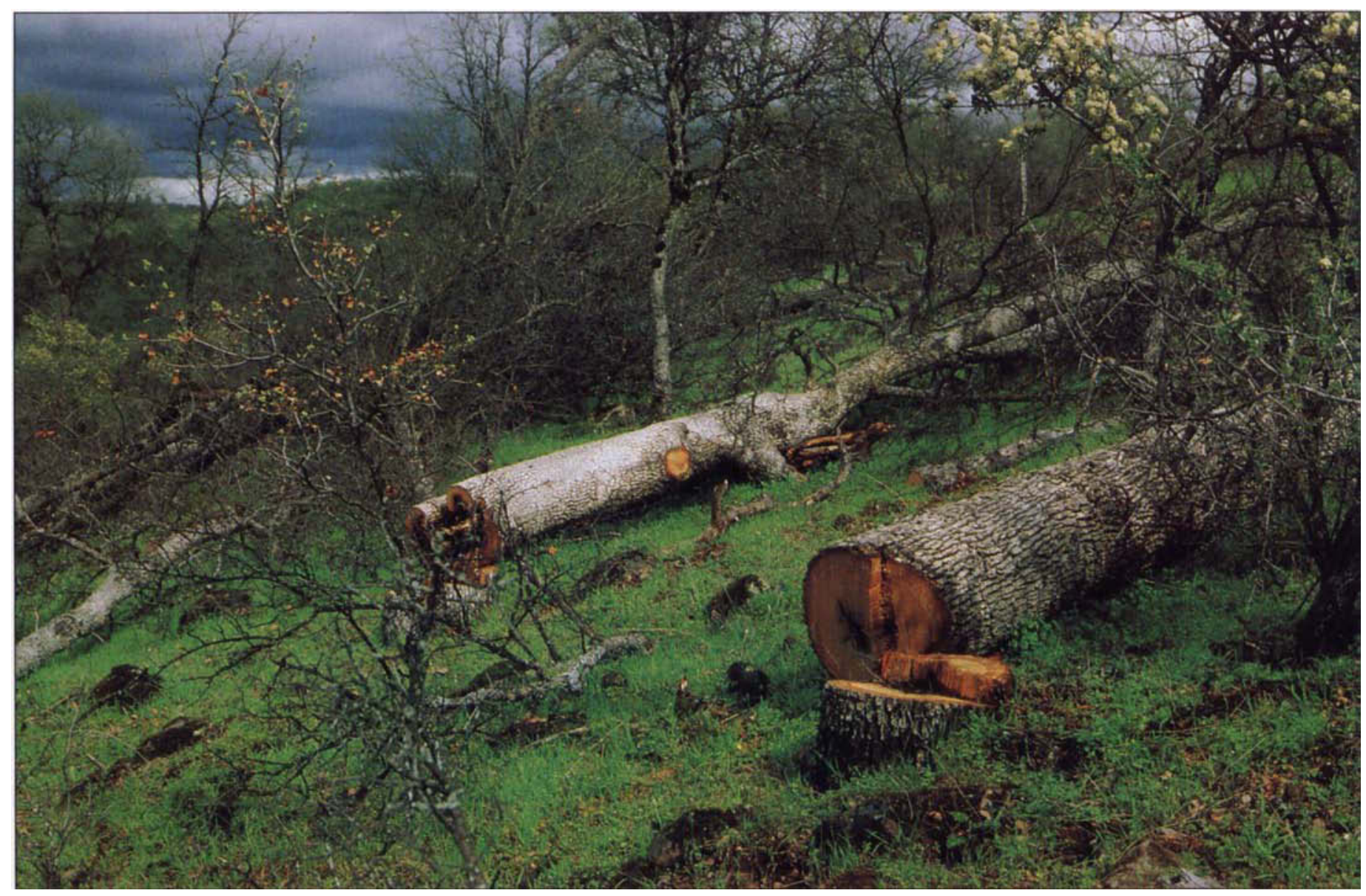

Firewood harvesting on hardwood rangelands was observed on 6,000 acres annually between 1988 and 1992.

\section{Aerial monitoring of hardwood} rangelands over a 4-year period revealed that almost 70,000 cords of firewood were harvested annually on approximately 6,000 acres. This represents less than $0.1 \%$ of the total hardwood rangeland in the state. Over $50 \%$ of the firewood volume harvested during these 4 years was in Shasta and Tehama counties, although these two counties represent less than $10 \%$ of the hardwood rangeland acreage in the state. In Tehama County, tree growth outpaced harvest, but in Shasta County, harvest exceeded growth by $30 \%$. Both counties' governments adopted resolutions calling for a retention of $30 \%$ crown cover following firewood harvest. This retention level attempts to balance the needs for profitable livestock management with wildlife habitat needs.

\title{
Impact of firewood harvesting on hardwood rangelands varies with region
}

\author{
Richard B. Standiford $\square$ Douglas McCreary $\square$ Sheila Barry \\ Larry Forero $\square$ Ron Knight
}

California's hardwood rangelands cover an estimated 7.4 million acres in the state. This area is characterized by an overstory canopy cover of at least $10 \%$ hardwood tree species, predominantly in the oak genus (Quercus spp.), with an understory of annual grasses and occasional native perennial grasses. Since European settlement of California, hardwood rangelands have been managed primarily for livestock production. These areas recently have taken on new importance as people realize hardwood rangelands provide one of the richest wildlife habitats in the state, with 331 vertebrate species relying at least partly on oak woodlands for habitat. Other public values provided by these areas include water quantity and quality, outdoor recreation and aesthetics. California's hardwood rangelands are unique in the West in that $80 \%$ of this acreage is privately owned. 

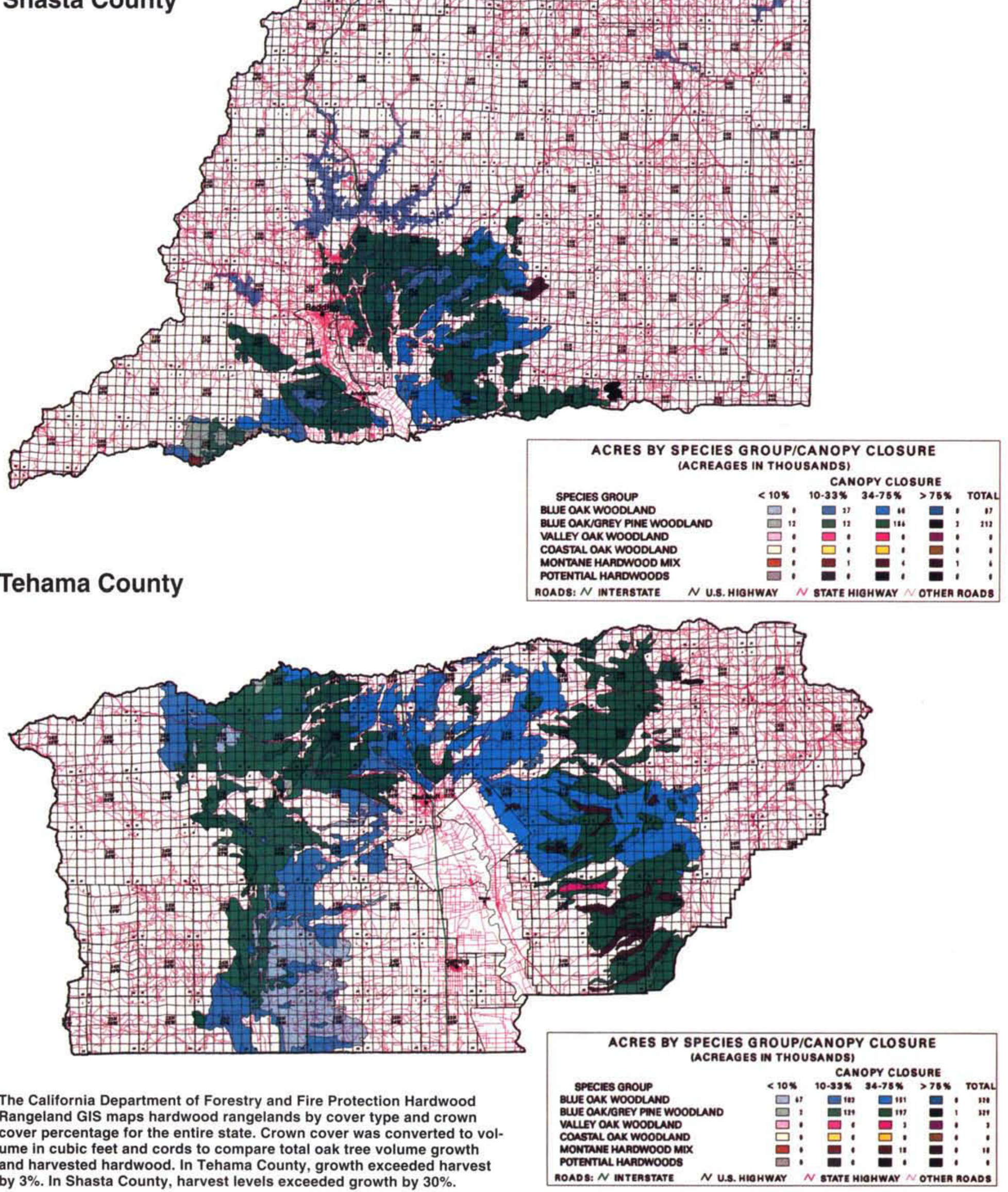


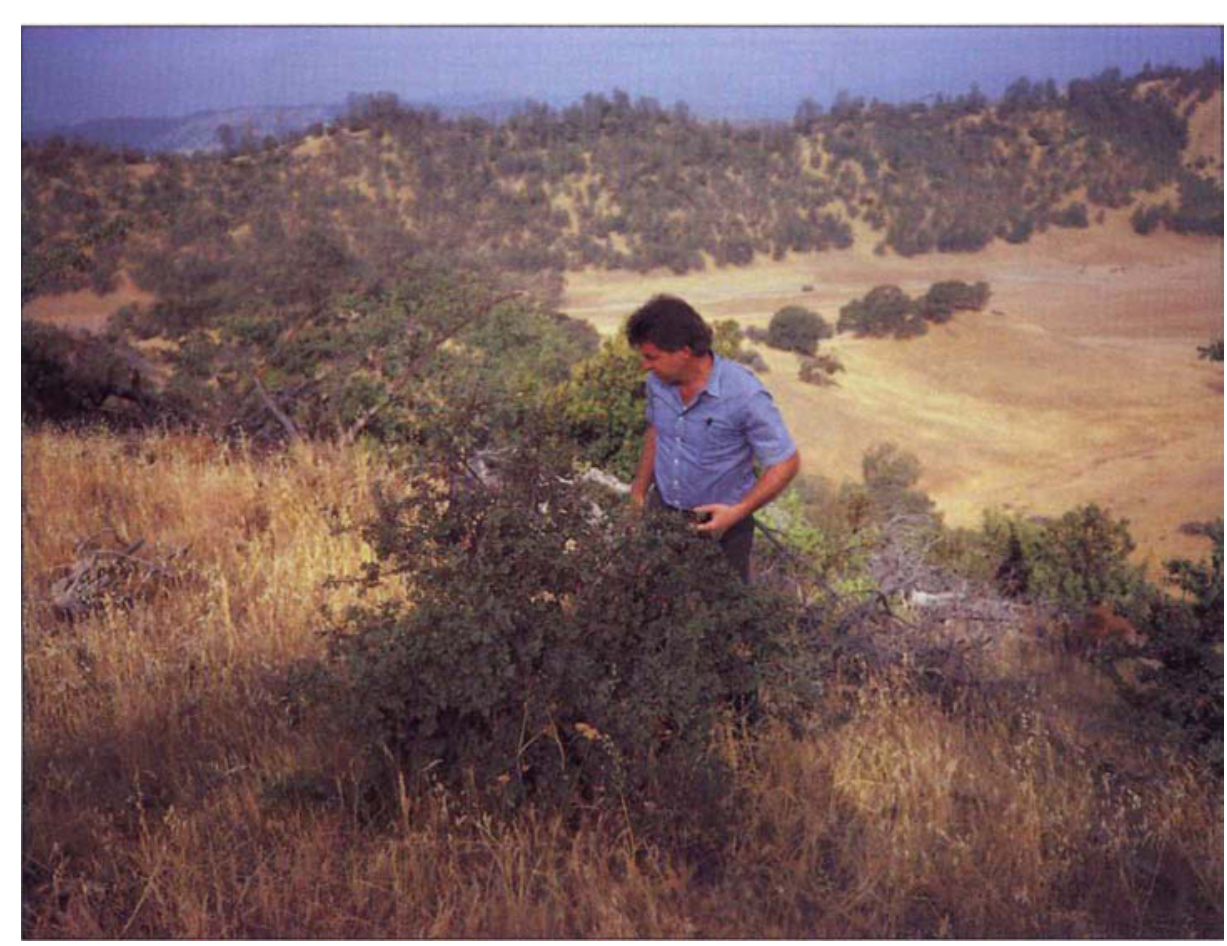

counting was made to shift acreage from its precut to its postcut canopy class.

In Tehama County, growth exceeded harvest by $3 \%$ for the 4 years of the survey (fig. 1). This approximate balance between growth and harvest indicates that for the short term, hardwood rangelands for the county as a whole are expected to remain fairly stable. In Shasta County, harvest levels exceeded growth by $30 \%$, indicating that current harvest levels will decrease volumes per acre and canopy cover. These levels of harvest likely would not be sustainable given the expected growth rates of the residual trees and the unharvested areas.

\section{Impacts on stand structure}

A relatively small percentage of hardwood rangeland acreage was harvested statewide, based on the 4-year aerial observation. On a statewide basis, the annual acreage of firewood harvest amounted to slightly more than 6,000 acres. This is significantly less than the 30,000 acres estimated by IHRMP and U.S. Forest Service to be converted each year to residential or commercial development. The regional impacts of firewood harvesting

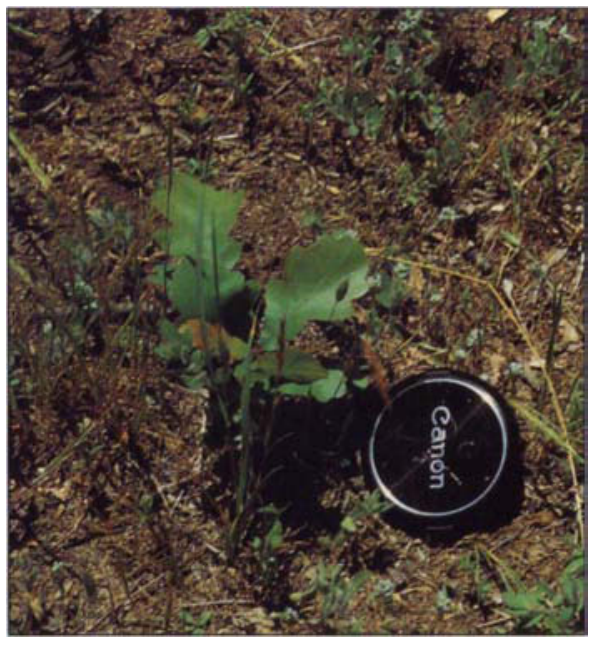

$\Delta$ Oak seedlings less than 1 foot in height were found on $39 \%$ of the sample plots in Shasta and Tehama counties following firewood harvest.

Specialist Standiford examines oak stump sprouts, which grew 1 to 3 feet annually following firewood harvest.

appear to be concentrated in the northern Sacramento Valley.

Volume and crown cover of hardwood rangelands are only one measure of impact from firewood harvest. To provide baseline information on hardwood rangeland stand structure following firewood harvesting, a study was initiated in 1993. The study, funded by the CDF, was conducted at the ranch level by IHRMP and Cooperative Extension offices in Shasta and Tehama counties. It assessed the intensity of harvesting that has taken place in the past 10 years, the effectiveness of regeneration by seedling and stump

\begin{tabular}{clcc}
\multicolumn{4}{c}{ TABLE 2. General characteristics of 103 sample plots on hardwood rangeland harvest sites in } \\
Shasta and Tehama counties \\
(harvests from 1985 to 1994)
\end{tabular}

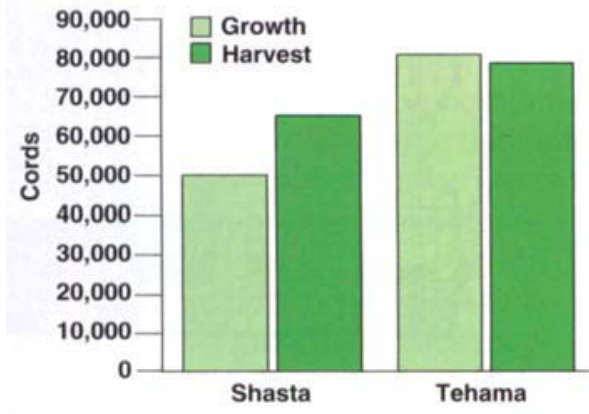

Fig. 1. Comparison of harvest and growth on hardwood rangelands in Shasta and Tehama counties, fall 1988 to fall 1992. 
sprouting, changes in wildlife habitat elements, and other stand structure characteristics. We also evaluated specific site factors to assess the spatial distribution of areas with adequate or inadequate regeneration.

This information will help in evaluating the effectiveness of current oak firewood harvesting practices on the long-term sustainability of the hardwood range resources in the Northern Sacramento Valley foothills.

Nineteen sample ranches were randomly selected -12 ranches in Tehama County and seven in Shasta County - in areas that had been harvested over the past 10 years. Information was collected from each study area on specific harvest location, date harvested, rainfall, soils, oak site index, precut and postcut canopy cover and diameter distribution, species composition and management practices. Data were collected on overstory trees, brush, stumps and resprouts in five to seven $1 / 10$-acre circular plots randomly located within each harvested area. A belt transect was established at each plot to assess seedling regeneration and brush cover. Additional data were collected at each plot on wildlife habitat elements, including snags, dead and down woody material, number of cavities and acorn production.

Table 2 shows the initial results from 103 sample plots on the 19 ranches. Average preharvest canopy cover in the two counties was fairly

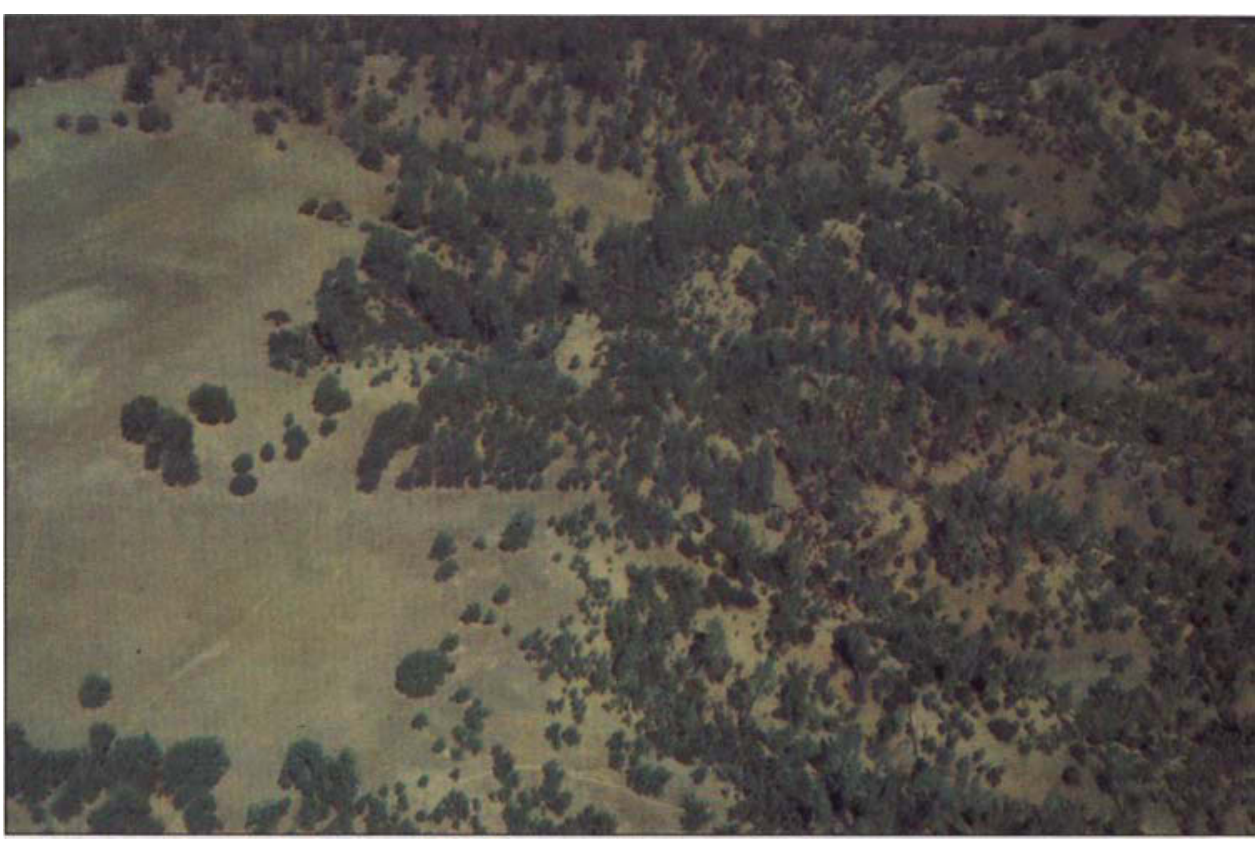

Aerial reconnaissance was carried out to evaluate preharvest and postharvest oak canopy between 1988 and 1992.

similar. However, preharvest volume levels and average tree size were higher in Shasta County. In general, harvest intensity was higher in Tehama County, with the average residual canopy lower than in Shasta County. There has been a trend, however, of increasing residual canopy level over the last 4 years in Tehama County. This may well reflect the success of educational programs presented at the local level by Cooperative Extension and other agencies. The average residual canopy in Shasta County was not significantly less than the $25 \%$ mini- mum threshold discussed in the IHRMP's guidelines.

There was a fairly high probability for stump sprouting of trees cut on hardwood rangelands in the two counties (fig. 2). Overall stump sprouting averaged more than $54 \%$. There was a strong negative correlation between stump diameter and sprouting success. Future studies will attempt to determine other site and management factors influencing sprouting success. There was an extremely low percentage of plots with naturally regenerated seedlings over 1 foot in height (table 2). This low probability, coupled with a

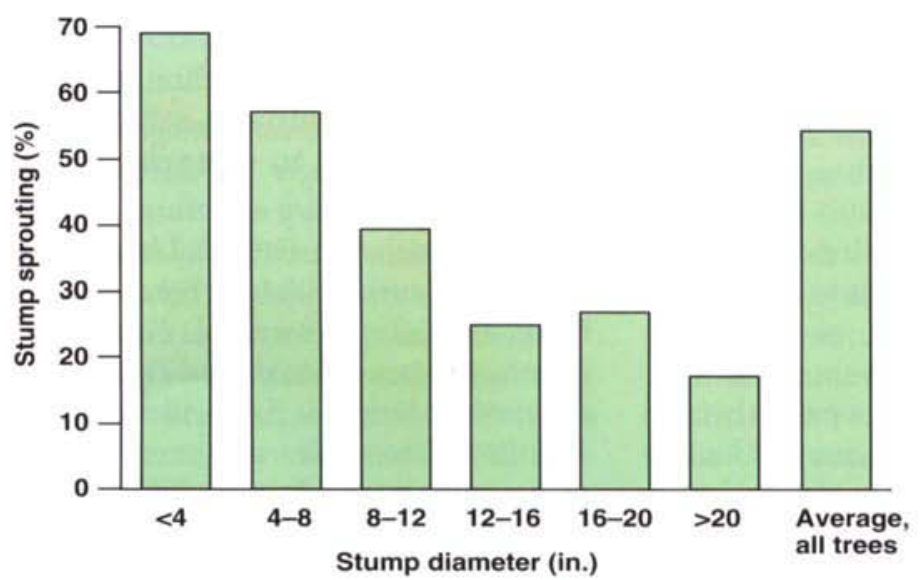

Fig. 2. Stump sprouting percent following firewood harvest in Shasta and Tehama counties.

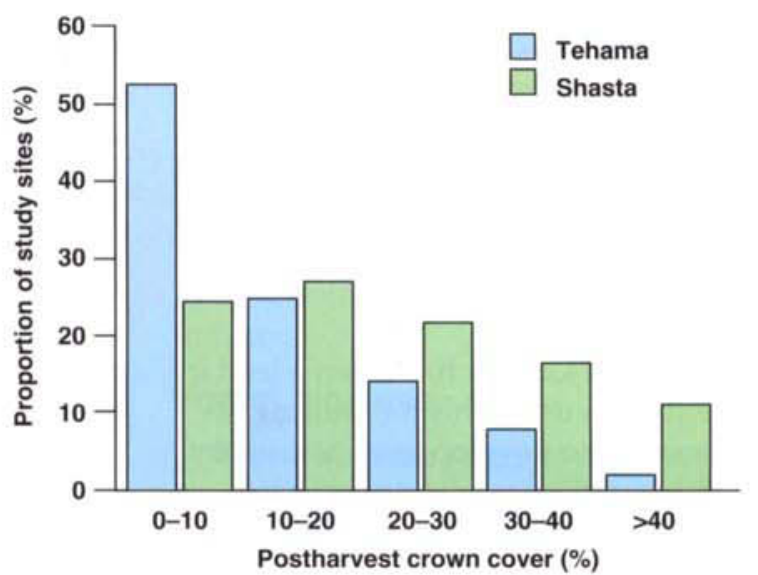

Fig. 3. Distribution of postharvest crown cover of 103 sample sites following firewood harvesting in Shasta and Tehama counties (harvests from 1985 to 1994). 


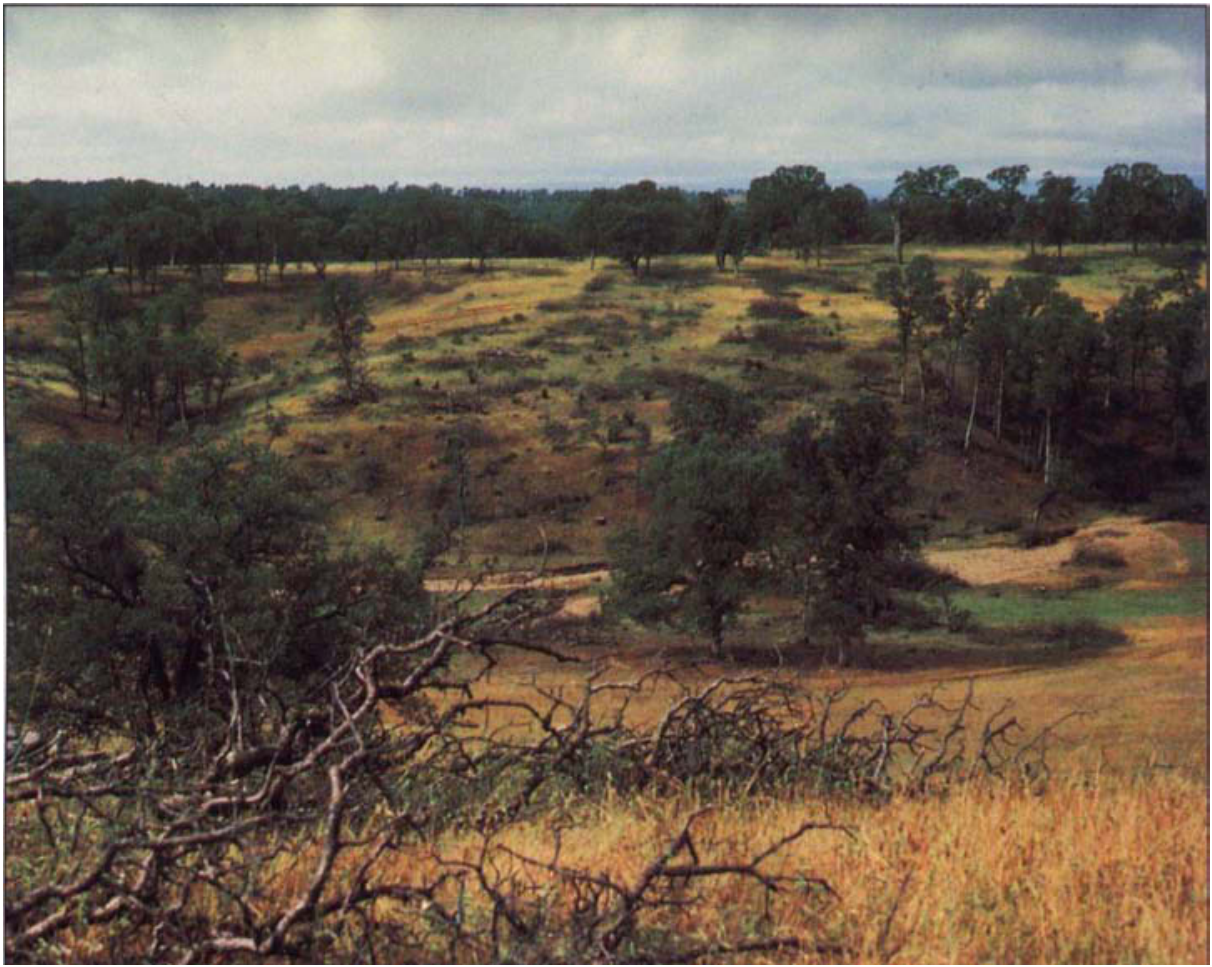

Residual oak canopy cover ranged from 0 to $\mathbf{5 0 \%}$ following firewood harvest in Shasta and Tehama counties.

slow growth rate, seems to suggest that stump sprouting will be the dominant method of regeneration in these stands following firewood harvest.

The overall effect of this general sprouting percentage and poor natural seedling regeneration is that these levels of oak harvest will result in hardwood rangeland stands with a lower crown density, fewer trees per acre, and a larger average tree size. Changes in overstory canopy also resulted in a higher proportion of harvested areas with dead and down woody debris and brush piles. Approximately $20 \%$ of the harvested plots had snags or granary trees, which could be used by wildlife. The effect of these stand level changes on biological diversity will be addressed in future studies.

\section{Policy direction}

Tehama County has taken a lead in the state in using this monitoring information to develop local, voluntary oak harvesting guidelines on hardwood rangelands. The county board of supervisors appointed an oak harvest committee to develop a county conservation strategy, which was adopted by the board in 1994. Because of the major impact of firewood harvesting in the county, the main emphasis of the policy was on firewood harvesting and retention standards. Shasta County followed suit, and has passed a voluntary oak management policy that will form the basis of its educational outreach.

Both the Shasta and Tehama counties resolutions call for a retention of $30 \%$ crown cover following firewood harvest. This retention level attempts to balance the needs for profitable livestock management with wildlife habitat needs. For Tehama County, less than $10 \%$ of the sample plots harvested in the past 10 years had over $30 \%$ canopy retention (fig. 3). For Shasta County, slightly more than $25 \%$ of the sample plots had over $30 \%$ canopy cover. Both county resolutions also call for educational outreach to convey these voluntary guidelines to landowners. Shasta and Tehama counties already have mailed a copy of their guidelines to all landowners of hardwood rangelands in the county. Increasing the proportion of stands that meet these locally derived retention standards is one measure of the success of this outreach. An increase in canopy retention in Tehama County over the past 5 years (from $7 \%$ to $16 \%$ retention) is a good indication that landowners are receptive to such efforts.

These assessments show that from a statewide perspective firewood harvest is not a dominant factor affecting hardwood rangelands. Regional differences in the sources of impacts to hardwood rangelands were well documented at 1993 Board of Forestry hearings on hardwood rangelands. On the basis of this information, the board decided to direct local governments to develop their own policies to conserve hardwood rangelands, rather than pass statewide regulations that might not apply to most of the state. Similar local voluntary initiatives are being developed in several other counties. These include countywide ordinances on tree removal, modifying the open space requirements of the county general plan to address hardwood rangelands, and developing hardwood rangeland criteria for California Environmental Quality Act review of specific projects, depending upon local factors that jeopardize the sustainability of hardwood rangelands.

It is critical that counties continue to monitor trends in harvest, regeneration and stand structure on hardwood rangelands. Data such as that gathered in the studies described here can help determine whether existing local policies are accomplishing the goal of conserving the public values derived from privately owned hardwood rangelands.

R.B. Standiford is Forest Management Specialist and Manager, IHRMP, UC Berkeley; D. McCreary is Natural Resources Specialist; S. Barry is Livestock Natural Resources Advisor, Tehama, Glenn and Colusa counties; L. Forero is Livestock Advisor, Shasta and Trinity counties; R. Knight is Farm Advisor

Emeritus, Tehama County.

For more information, see Pillsbury, N., M. DeLasaux, R. Pryor, and W. Bremer, 1991. Mapping and GIS Database Development for California's Hardwood Resources. California Dept. of Forestry and Fire Protection, Sacramento. 